The Garden in the Machine 
The publisher gratefully acknowledges the generous contribution to this book provided by the General Endowment Fund of the Associates of the University of California Press. 


\section{Scott MacDonald}

\section{The Garden in the Machine}

A Field Guide to Independent Films about Place 
University of California Press

Berkeley and Los Angeles, California

University of California Press, Ltd.

London, England

(C) 200 I by the Regents of the University of California

Earlier versions of several chapters, or portions of chapters, have been published previously; the later versions are reprinted here by permission: "The Garden in the Machine," in Prospects 22 (I997): 239-62; "Voyages of Life," in Wide Angle I8, no. 2 (April I996): IOI-26; "Re-envisioning the American West," in American Studies 39, no. I (spring I998): II5-46; "From the Sublime to the Vernacular," in Film Quarterly 53, no. I (fall I999): I2-25; portions of the "The City as Motion Picture," in Film Quarterly 5I, no. 2 (winter 1997-98): 2-20, and in Wide Angle 19, no. 4 (October I997): I09-30; and "The Country in the City," in Journal of American Studies 3I, no. 3 (winter I997): 337-60.

Library of Congress Cataloging-in-Publication Data

MacDonald, Scott, I942 -

The Garden in the machine : a field guide to independent films about place / Scott MacDonald.

p. $\quad \mathrm{cm}$.

Includes bibliographical references and index.

ISBN O-520-22737-9 (cloth : alk. paper). -

ISBN 0-520-22738-7 (pbk. : alk. paper)

I. Experimental films - History and criticism.

2. Motion pictures - Setting and scenery. I. Title.

PNI995.9.E96 M344 200I

79I.43'-dc2I

Manufactured in Canada

$\begin{array}{llllllllll}10 & 09 & 08 & 07 & 06 & 05 & 04 & 03 & 02 & \text { OI }\end{array}$

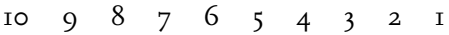

The paper used in this publication meets the minimum requirements of ANSI/NISO Z39.48-I992 (R I997) (Permanence of Paper). $\otimes$ 
For Patricia Reichgott O'Connorlover, partner, family, advisor, witnessthis book begins and ends with you. 
This page intentionally left blank 
We have advanced by leaps to the Pacific, and left many a lesser Oregon and California unexplored behind us.

HENRY DAVID THOREAU, THE MAINE WOODS 
This page intentionally left blank 